\title{
HEAVY METALS «VERSUS»CLAY MINERALS IN THE QUATERNARY SEDIMENTS OF THE CORTEGAÇA BEACH FORMATION (OVAR, PORTUGAL)
}

\author{
A. MACHADO*, A. P. SILVA*, F. ROCHA* \& C. GOMES
}

Abstract

Resumo

The site under study (Cortegaça beach) belongs to the Ovar municipality and is part of an extensive region characterized by flat terrains, consisting mainly of old beach and dunar deposits. Coastal erosion had exposed the so called Cortegaça beach formation showing the following three sedimentary sequences, from the basis to the top: 1) greenish sandy clay; 2) sand layers with marked cross-bedded showing on top a bioturbated podzol; 3) bioturbated beach sand and dune sand. The main goal of the present paper is the establishment of relationships between heavy metals nature and content with the mineral composition, particularly of the clay component, of those sediments. The study of the fine fraction (less than $38 \mathrm{~mm}$ ) of forty samples collected along three profiles has been carried out. X-ray diffraction was used for mineralogical determinations, whereas atomic absorption spectrometry was used for the determination of the heavy metals: $\mathrm{Cu}, \mathrm{Ni}, \mathrm{Co}, \mathrm{Zn}, \mathrm{Pb}, \mathrm{Cd}, \mathrm{Mn}$ and $\mathrm{Cr}$. Mineralogical studies made evident a gradual vertical evolution marked by the following main features: 1) dominance of quartz and phyllosilicates in the fine fraction associated to discrete amounts of feldspar and other accessory minerals; evaporite minerals and iron hydroxides are particularly important in some thin layers; 2) general dominance of illite over kaolinite in the clay fraction with oscillations of the illite/kaolinite content. As regards with heavy metals content the following facts deserve to be emphasized: 1) $\mathrm{Pb}$ and $\mathrm{Cu}$ are more concentrated in the sandy layers showing cross-bedded, whenever iron hydroxides are enriched; 2) $\mathrm{Zn}, \mathrm{Cr}$ and less clearly, $\mathrm{Ni}, \mathrm{Co}$ and $\mathrm{Cd}$ behave differently of $\mathrm{Pb}$ and $\mathrm{Cu} ; 3) \mathrm{Mn}$ is clearly enriched at the top of the 3rd sequence. For the typification and hierarchization of the relationships between the mineralogical and the chemical variables geostatistical analysis has been carried out using, in particular, both Principal Components Analysis and Cluster Analysis.

Key-words: Heavy metals, clay minerals, Quaternary sediments

Metais pesados «versus» minerais argilosos nos sedimentos Ouaternários da «Formação da Praia de Cortegaça» (Ovar, Portugal) — O local estudado (Praia de Cortegaça) pertence ao concelho de Ovar e faz parte de uma vasta região caracterizada por extensas zonas aplanadas, em grande parte ocupada por depósitos de praias antigas, com o litoral bordejado por depósitos dunares, formando pequenas elevações. A erosão costeira pôs a descoberto uma formação designada por Formação da Praia de Cortegaça, constituída da base para o topo por: argila arenosa esverdeada sobreposta por estratos de areia com estruturas sedimentares (estratificação cruzada). Por cima dos estratos de areia ocorre um podzol com horizontes-bioturbados. Por fim, no topo dos perfis estudados ocorrem areias de praia com biortubação e areias de duna. O objectivo essencial do presente trabalho é caracterizar estas formações no que se refere ao seu conteúdo em metais pesados e confrontar esse conteúdo com a composição mineral das fracções finas, em particular da fracção argilosa. Foram estudadas 40 amostras, colhidas ao longo de três perfis na zona em estudo. Os estudos mineralógicos foram efectuados utilizando, essencialmente, a Difracção de Raios X. Por Espectrometria de Absorção Atómica foram determinados os conteúdos em $\mathrm{Cu}, \mathrm{Ni}, \mathrm{Co}, \mathrm{Zn}, \mathrm{Pb}, \mathrm{Cr}, \mathrm{Cd}$ e Mn. As análises mineralógicas efectuadas evidenciam uma evolução vertical da composição mineral, salientando-se os seguintes aspectos principais: 1) no que se refere à fracção fina, predomínio generalizado do quartzo e dos filossilicatos, acompanhados por feldspatos e por um conjunto muito discreto de minerais acessórios, com ocorrência de secções nas quais hidróxidos de ferro e minerais evaporíticos assumem particular importância; 2) no que se refere à fracção argilosa, predomínio generalizado da ilite com oscilações dos teores relativos da caulinite e da ilite. No que se refere aos conteúdos em metais pesados, importa salientar o seguinte: 1) a relativa concentração de $\mathrm{Pb}$ e $\mathrm{Cu}$ nas secções intermédia e superior da 2 sequência, rica em hidróxidos de Ferro; 2) $\mathrm{Cr}$ e $\mathrm{Zn}$ assim como, menos nitidamente, Ni, Co e Cd apresentam um comportamento oposto ao do $\mathrm{Pb}$ e $\mathrm{Cu}$; 3) a notória concentração do Mn no topo dos perfis estudados, isto é, na $3^{\text {a }}$ sequência. A fim de melhor tipificar e hierarquizar as relações entre as variáveis químicas e mineralógicas procedeu-se à sua análise geoestatística, recorrendo em particular aos métodos de Análise de Componentes Principais (ACP) e de Classificação Hierárquica.

Palavras-chave: Metais pesados, minerais argilosos, sedimentos Quaternários

\section{INTRODUCTION}

The site under study (Cortegaça beach) belongs to the Ovar municipality and is part of an extensive region characterized by flat terrains, consisting mainly of old beach and dunar deposits (Fig. 1).

In the littoral to the north of Aveiro, coastal erosion exposed the so-called Praia de Cortegaça Formation

\footnotetext{
* Departamento de Geociências, Universidade de Aveiro, 3810 Aveiro.
} 


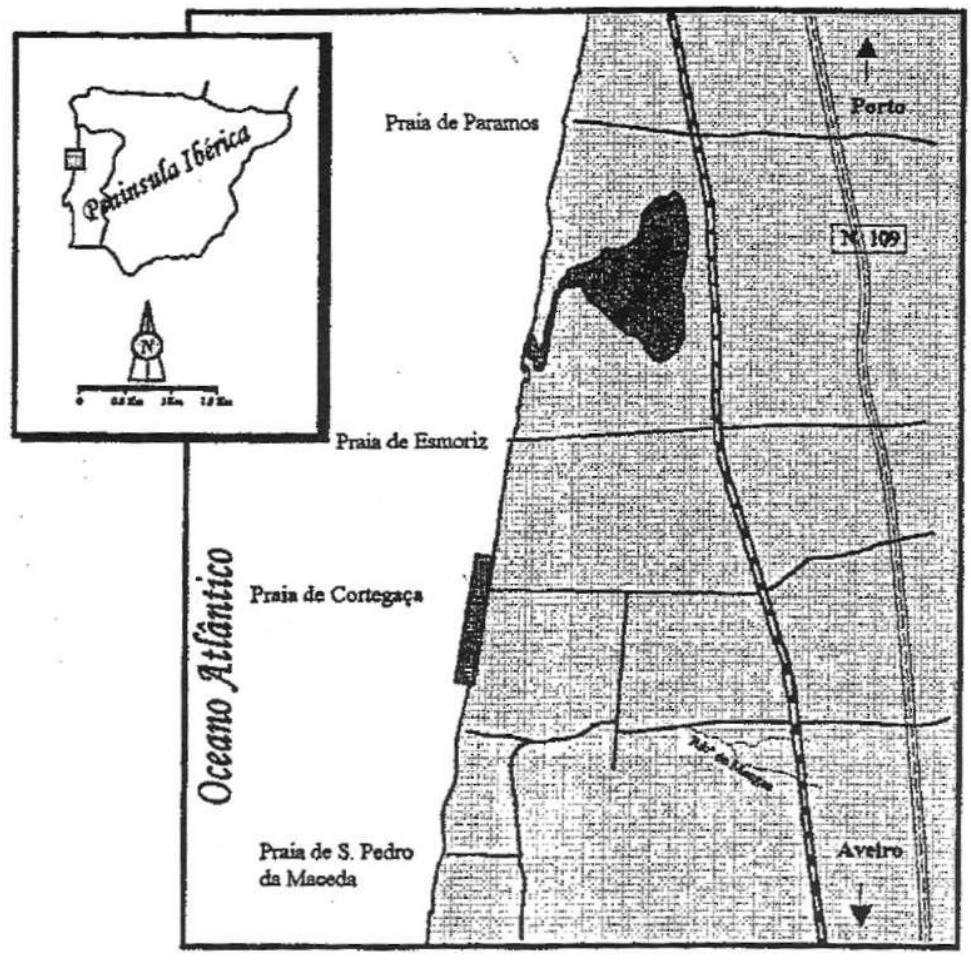

Figure 1 - Location of the studied area.

Figura 1 - Localização da área estudada.

(GRANJA \& CARVALHO, 1991, 1994) consisting, from the base to the top, of: greenish fine silty-clayey sand overlied by sandy unit exhibiting cross-bedding. Coal fragments incorporated in the greenish fine silty-clayey sand allowed a radiocarbon datation providing values in the range $6850 \pm 60$ to $5500 \pm 160$ years BP. Overlying the sandy unit lies a podzol exhibiting bioturbated horizons. Datation carried out on coal fragments incorporated in the podzol provided values in the range $3490 \pm 60$ to $950 \pm 80$ years BP. Finally, at the top of the cross-sections of the studied outcrops lie bioturbated beach sands and dune sands.

The use of the fine fractions (silt and clay) minera$\operatorname{logy}$ for the establishment of a fine vertical zonography was presented and discussed in previous papers (MACHADO et ai, 1995; SILVA et ai, 1997). Such vertical zonography allowed the discrimination and characterization of the climatic oscillations that did occur both in the surrounding continental sediments source areas and in the sedimentation environment. A morphoclimatic reconstruction could be put forward as well.

GRANJA \& CARVALHO (1991, 1994) did present the geologic setting of the Praia de Cortegaça formation, and did put forward stratigraphic and environmental analysis. Detailed description of the studied profiles as well as their positioning were presented by MACHADO et ai. (1995) and SILVA et ai (1997).
The main goal of the present paper is the establishment of statistical relationships between heavy metals nature and content with the mineral composition, particularly of the silt and clay components, of the studied sediments.

\section{MATERIALS AND METHODS}

The study of the fine fractions (less than $38 \mathrm{~mm}$ ) and clay fractions (less than $2 \mathrm{~mm}$ ) of forty samples collected along three beach profiles has been carried out.

Mineralogical studies were based mainly on $x$-ray diffraction (XRD) determinations, carried out on both the less than $38 \mathrm{um}$ and $2 \mathrm{um}$ fractions. For the semi-quantitative determination of clay minerals, criteria recommended by SCHULTZ (1964) and THOREZ (1976) were followed.

Chemical analyses of the heavy metals $(\mathrm{Cu}, \mathrm{Ni}$, $\mathrm{Co}, \mathrm{Zn}, \mathrm{Pb}, \mathrm{Cd}, \mathrm{Mn}$ and $\mathrm{Cr}$ ) in the less than $38 \mathrm{um}$ fractions were undertaken, using atomic absorption spectrometry.

For the present study the northmost located of the three profiles was chosen due to the fact of being the most representative and well sampled.

Statistical Analysis, Univariate and Multivariate Factorial (Principal Components) and Cluster Analysis, of the analytical data were carried out. 
As LOPEZ-AGUAYO \& GONZALEZ LOPEZ (1995) remark, the use of the Multivariate Factorial Analysis statistical methods, as outlined by IMBRIE \& VAN ANDEL (1964), JORESKOG et al. (1976), DAVIS (1986) and REYMENT \& JORESKOB (1993), allowed us a good characterization of the system data, reducing the complexity of the model and classifying the variables and samples into natural groups (MEZZADRI \& SACCANI, 1989).

\section{RESULTS AND DISCUSSION}

A preliminary study of the mineralogical composition, in particular of the clay fraction, from the sediments of Praia de Cortegaça formation was carried out by MACHADO et al. (1995). In general terms, the different lithological units are characterized by the dominance of Mite, having source most probably on phyllitic rocks, which are quite widespread in regional terms. Kaolinite is abundant also in some units, whereas Smectite, Chlorite, Vermiculite and irregular 10-14 A Interstratifications are the accessory clay minerals. Iron hydroxides and evaporitic minerals are present in some units.

Later on, SILVA et al. (1997) disclosed the existence of a gradual vertical evolution characterized by the following main features:

- dominance of Quartz and Phyllosilicates in the fine fraction associated to discrete amounts of Feldspar and other accessory minerals;

- evaporite minerals and iron hydroxides are particularly important in some thin layers;

- general dominance of Mite over Kaolinite in the clay fraction with oscillations of the Illite/Kaolinite content.

This vertical evolution allowed the clear discrimination of the three sedimentary sequences, from the basis to the top (SILVA et al, 1997):

1. greenish sandy clay;

2. sand layers characterized by marked cross-bedding showing on its top a bioturbated podzol;

3. bioturbated beach sand and dune sand.

According to SILVA et al. (1997) the Mite dominance in sequence 1 expresses an environment characterized by low hydrodinamism whereas its gradual enrichment towards the sequence top means that the environment became progressively more confined and lagunar. The environment changed from a littoral one, supramareal, to a lagunar one and finally to an evaporitic one. Sequence 2 expresses at its base the effects of a transgression, since a littoral or a transition environment changed progressively to a lagunar one, very confined, that later on changed to a continental air exposed one where a soil with the characteristics of a podzol could be developed. Sequence 3 is initiated with beach sand and ends up with dune sand.

On the basis of the qualitative and quantitative mineralogy, the same authors (op. cit.) presented a reconstruction of the climate prevailing at the time of the sedimentary processes responsible for the formation of the different sequences. In sequence 1 , the significant amounts, approximately equivalent, of Mite and Kaolinite present expresses a temperate climate with low contrasting seasons. In sequence 2 , climate would be also, temperate, however not so warm as the one corresponding to sequence 1 . In sequence 3 the prevailing temperate climate changed progressively to a climate characterized by lower temperature and rainfall.

To analyse the virtual climatic oscillations the following parameters had been used by SILVA et al. (1997): Illite/Kaolinite, Mite + Chlorite/Kaolinite + Vermiculite and the Kubler crystallinity index for Mite. Interpretation of these parameters allowed the definition of ten climatic alternating episodes, either warmer and weter or cooler and dryier.

Figure 2 shows, for the selected profile, the vertical evolution of the minerals whose existence influences heavy metals presence.

The observation of Figure 2 shows that Phyllossilicates are abundant in the first sedimentary sequence (samples 1 to 7 ), defined by SILVA et al. (1997), that ends up with an iron rich duricrust; in the second sequence (samples 8 to 15 ), do occur significant quantities of Sulfates and other evaporitic minerals that disapear towards the sequence top, i.e. in the podzol horizons in which Phyllosilicates become clearly represented; in the third sequence (samples 16 and 17) a decrease on Phyllosilicates content is observed.

Figure 3 shows the vertical evolution, in the same profile, of the analysed heavy metals $(\mathrm{Cu}, \mathrm{Ni}, \mathrm{Co}, \mathrm{Zn}$, $\mathrm{Pb}, \mathrm{Cd}, \mathrm{Mn}$ and $\mathrm{Cr}$ ).

As regards with heavy metals content the following facts deserve to be emphasized:

- $\mathrm{Pb}$ and $\mathrm{Cu}$ are more concentrated in the sandy layers showing cross-bedding of the second sedimentary sequence, whenever iron hydroxides are enriched;

- Zn, Cr and less clearly, Ni, Co and Cd behave differently of $\mathrm{Pb}$ and $\mathrm{Cu}$ being more concentrated in the clay enriched layers;

- Mn is clearly enriched at the top of the third sequence.

Figures 4 and 5 show the correlation between each of the eight analysed heavy metals and the Phyllosilicates content. 


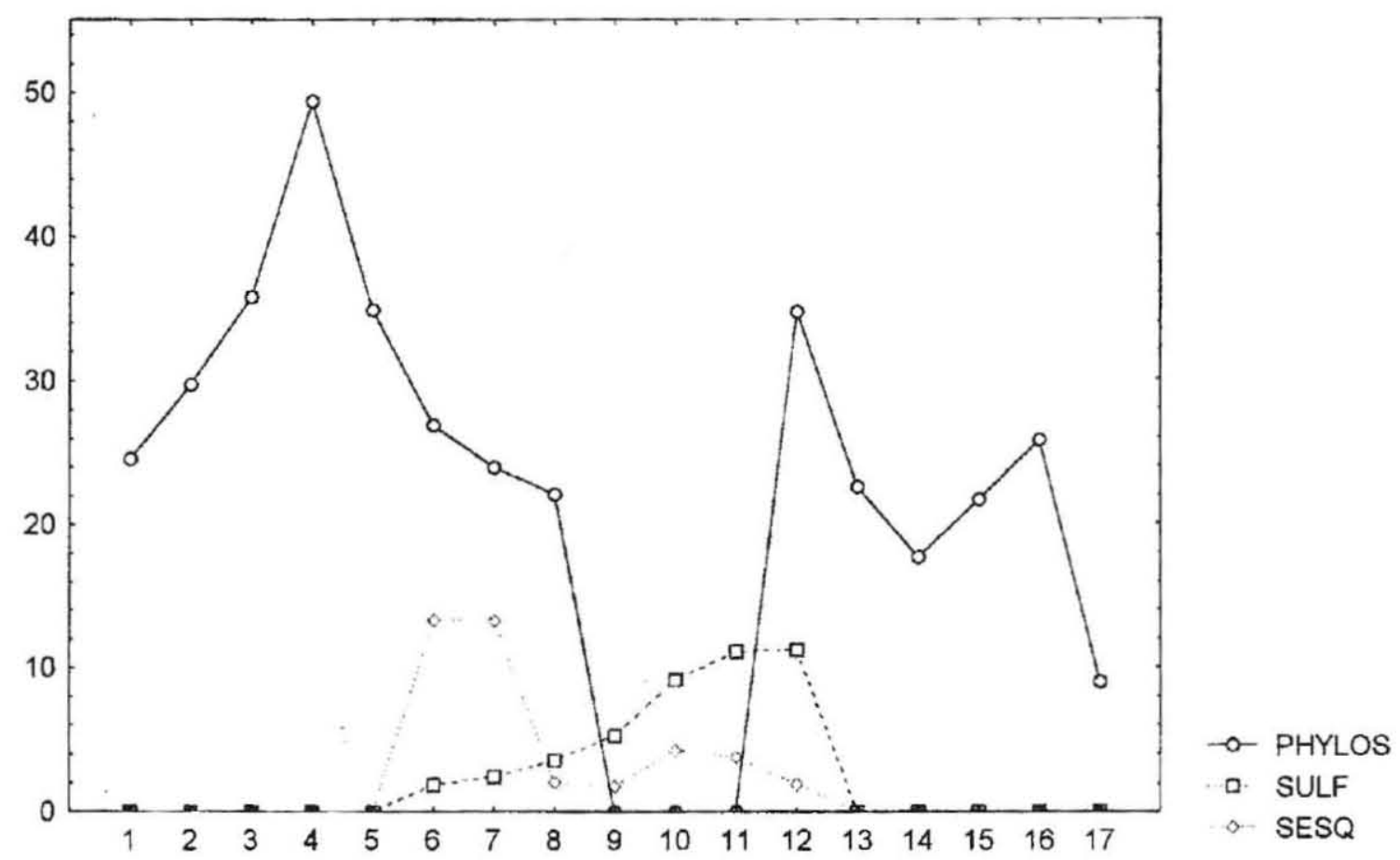

Figure 2 - Vertical evolution of minerals having some influence on heavy metals fixation.

PHYLOS - Phyllosilicates,

SULF - Sulfates and other evaporitic minerals;

SESQ - Iron Oxides/Hydroxides (Sesquioxides)
Figura 2 - Evolução vertical dos minerais que podem ter alguma influência na fixação dos metais pesados.

PHYLOS - Filossilicatos,

SULF - Sulfatos e outros minerais evaporiticos;

SESQ - Óxidos/Hidróxidos de Ferro (Sesquióxidos)

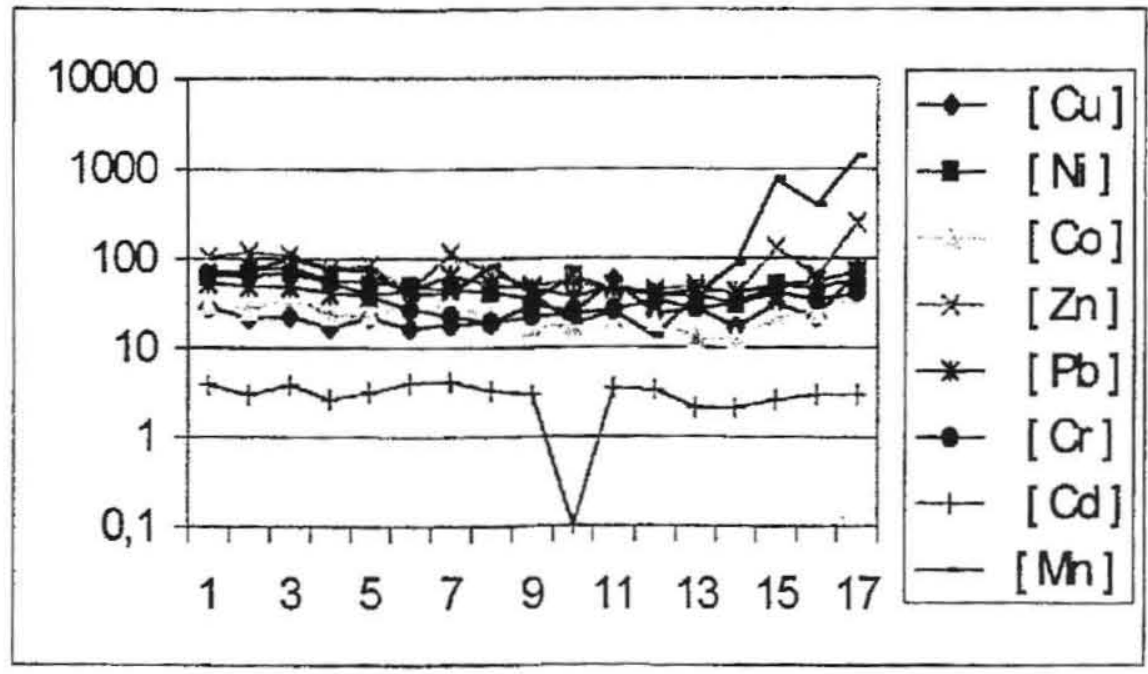

Figure 3 - Vertical evolution of the analysed heavy metals: $\mathrm{Cu}, \mathrm{Ni}, \quad$ Figura 3 - Evolução vertical dos metais pesados analisados: Cu, Ni, $\mathrm{Co}, \mathrm{Zn}, \mathrm{Pb}, \mathrm{Cd}, \mathrm{Mn}$ and $\mathrm{Cr}$. 

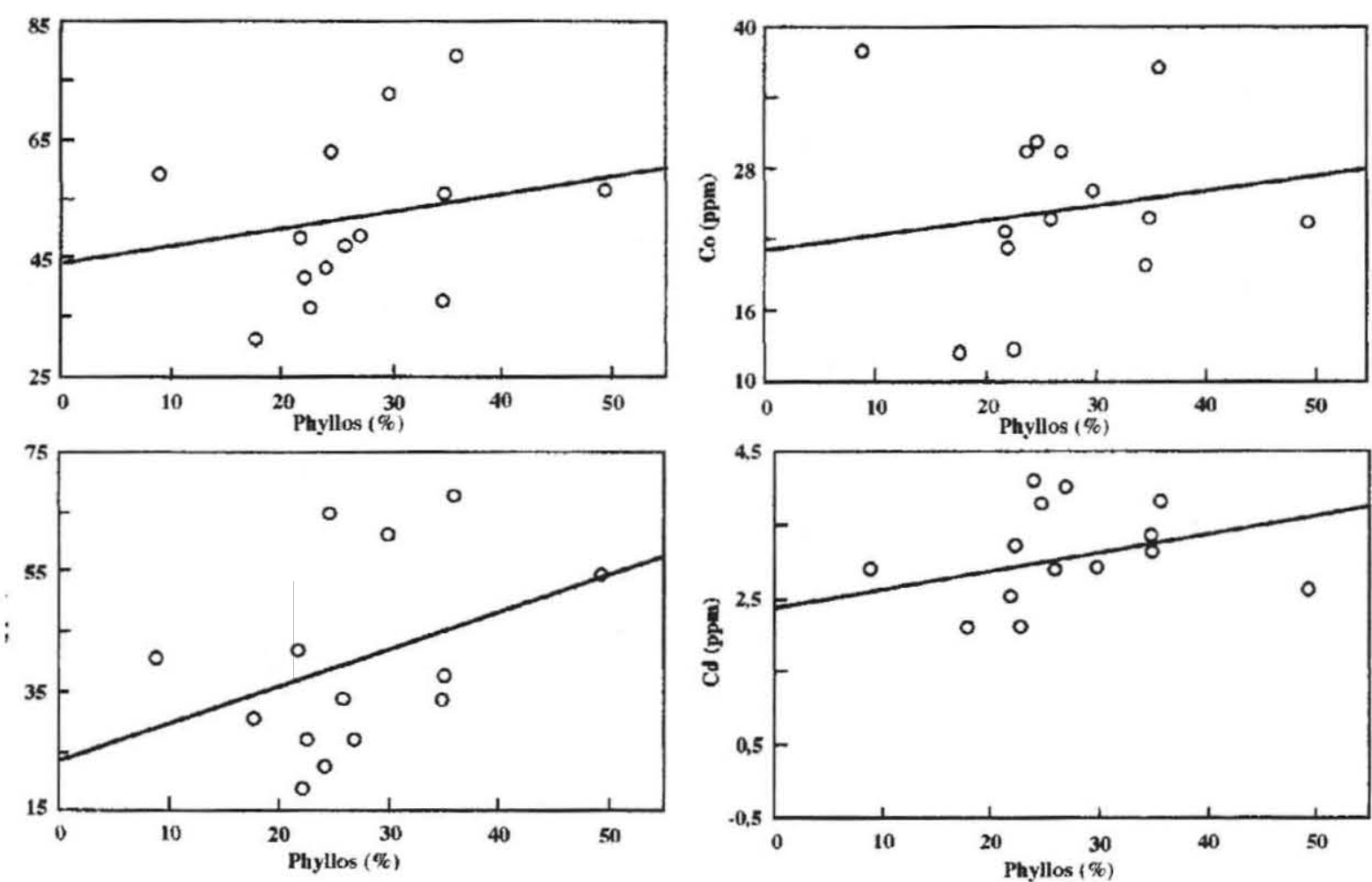

Figure 4 - Positive correlations between the analysed heavy metals and the Phyllosilicates contents.

Figura 4 - Correlações positivas entre os metais pesados analisados e o conteúdo de Filossilicatos.
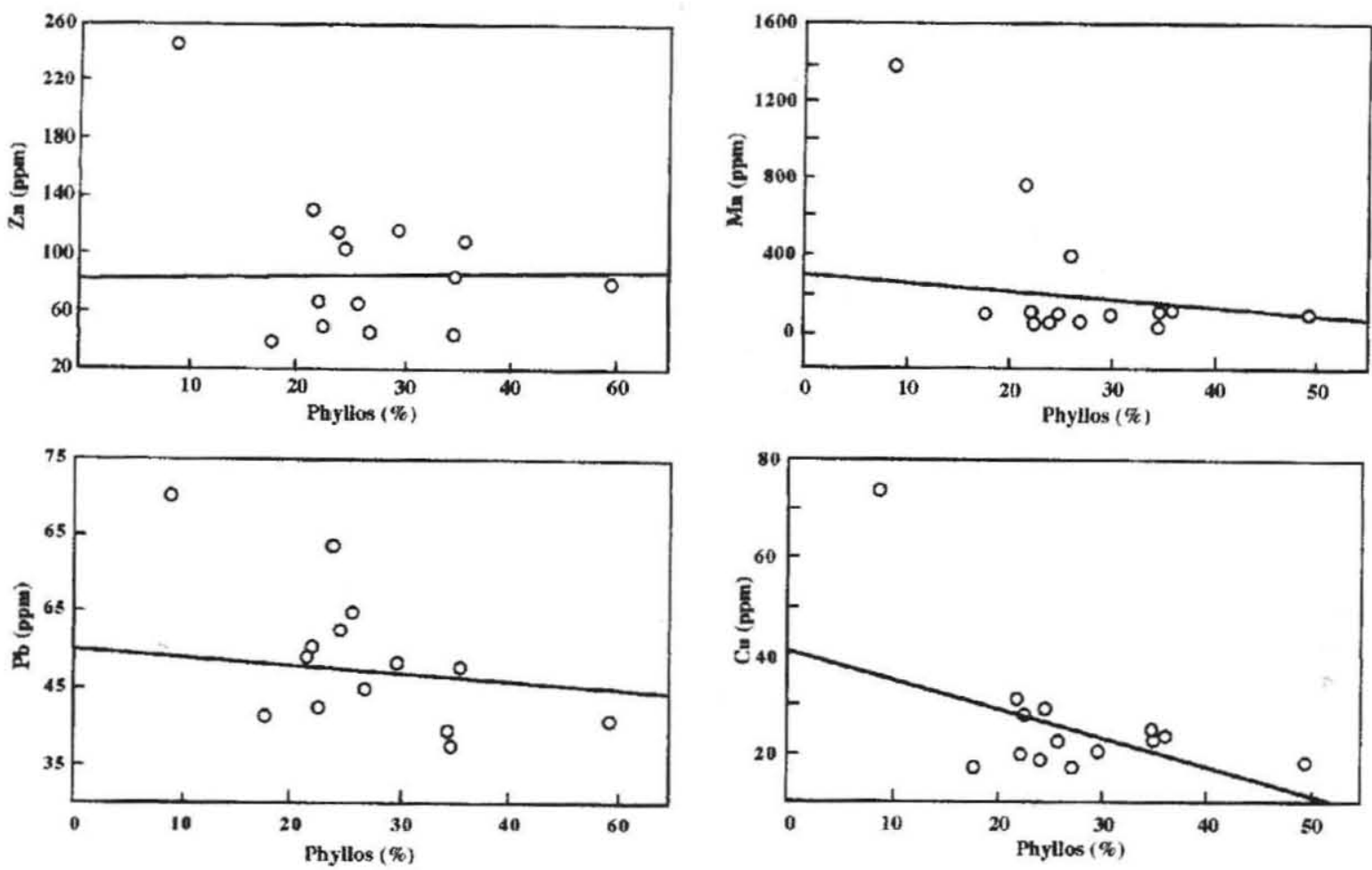

Figure 5 - Negative correlations between the analysed heavy metals and the Phyllosilicates contents.

Figura 5 - Correlações negativas entre os metais pesados analisados e o conteúdo de Filossilicatos. 
The analysis of Figures 4 and 5 shows that in spite of the notorious dispersion of sample representative points it is possible to assemble the analysed heavy metals in three groups:

1. one that correlates positively $\mathrm{Ni}, \mathrm{Cd}, \mathrm{Cr}$ and Co with Phyllosilicates content;

2. other that correlates negatively $\mathrm{Mn}, \mathrm{Pb}$ and $\mathrm{Cu}$ with Phyllosilicates content;

3. another one includes $\mathrm{Zn}$ and does not show any correlation with Phyllosilicates content.

For the typification and hierarchization of the relationships between the mineralogical and the chemical variables, geostatistical analysis has been carried out using, in particular, both Principal Components Analysis and Cluster Analysis.

Figure 6 shows a plot of the analysed variables on the first factorial plane. Its analysis enhances the control of clay minerals (except Mite) over heavy metals, $\mathrm{Cr}$ and $\mathrm{Ni}$ in particular.

Cluster analysis of the same variables (Figure 7) supports and stresses these observations, since it shows a clear relationship between Phyllosilicates and $\mathrm{Cr}$ and $\mathrm{Ni}$.
4. CONCLUSIONS

From the results of the studies disclosed in this paper we can conclude:

1. the analysed heavy metals behave differently; $\mathrm{Pb}$ and $\mathrm{Cu}$ are more concentrated in the sandy layers showing cross-bedding of the second sedimentary sequence, whenever iron hydroxides are enriched; $\mathrm{Zn}, \mathrm{Cr}$ and less clearly, $\mathrm{Ni}, \mathrm{Co}$ and $\mathrm{Cd}$ are more concentrated in the clayey layers; $\mathrm{Mn}$ is clearly enriched at the top of the third sequence;

2. $\mathrm{Ni}, \mathrm{Cd}, \mathrm{Cr}$ and Co correlate positively with Phyllosilicates content;

3. there is a clear control of clay minerals (except Mite) over heavy metals, $\mathrm{Cr}$ and $\mathrm{Ni}$ in particular.

The existence of a positive correlation between $\mathrm{Cu}$ and $\mathrm{Pb}$ and $\mathrm{Fe}$ - and $\mathrm{Mn}$-hydroxides had been referred to by several authors, such as MOSSER (1980) and BUTCHER et al. (1994). On the other hand, $\mathrm{Zn}, \mathrm{Cr}, \mathrm{Ni}$, $\mathrm{Co}$ and $\mathrm{Cd}$ are trace elements commonly associated with clay minerals, more to $7 \mathrm{~A}$ and $14 \mathrm{~A}$ than to $10 \mathrm{~A}$ clay minerals (Mosser, 1980; BUTCHER et al., 1994).

\section{Factor Loadings, Factor 1 vs. Factor 2 \\ Rotation: Unrotated \\ Extraction: Principal components}

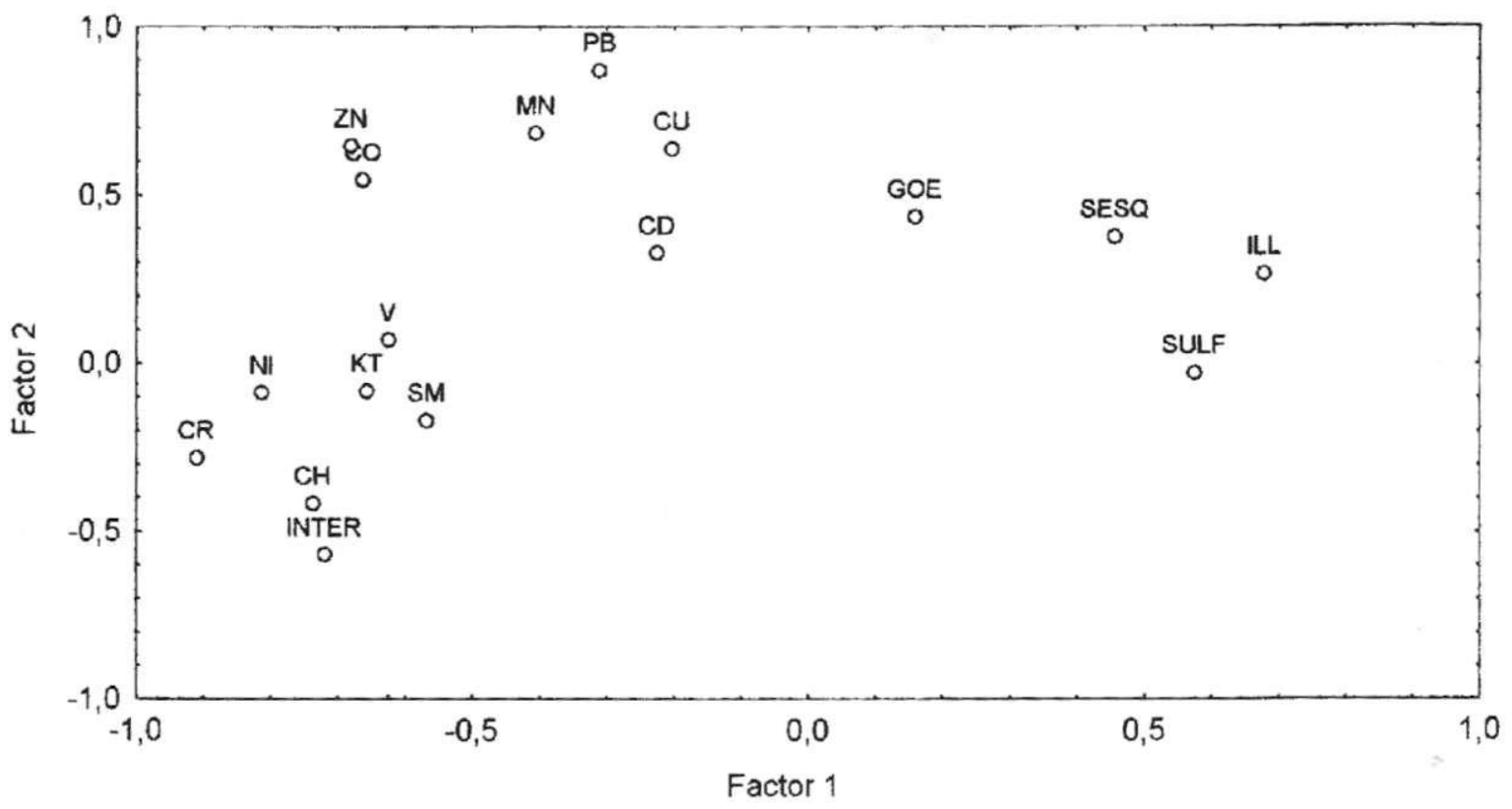

Figure 6 - Plot of the analysed variables on the first factorial plane. $\mathrm{CH}$ - Chlorite, GOE - Goethite, ILL - Illite, INTER 10-14 Å Interstratifications, KT - Kaolinite, SESQ - Iron Sesquioxides, SM - Smectite, SULF Sulfates and other evaporitic mineralsV- Vermiculite
Figura 6-Projecção das variáveis analisadas no primeiro plano factorial.

CH - Clorite, GOE - Goethite, ILL - Ilite, INTER Interestratificados 10-14 $\AA$, KT - Caulinite, SESQ Sesquióxidos de ferro,

$\mathrm{SM}$ - Esmectite, SULF - Sulfatos e outros minerais evaporíticos, $\mathrm{V}$ - Vermiculite 


\section{Tree Diagram for 11 Variables \\ Ward's method \\ 1-Pearson $r$}

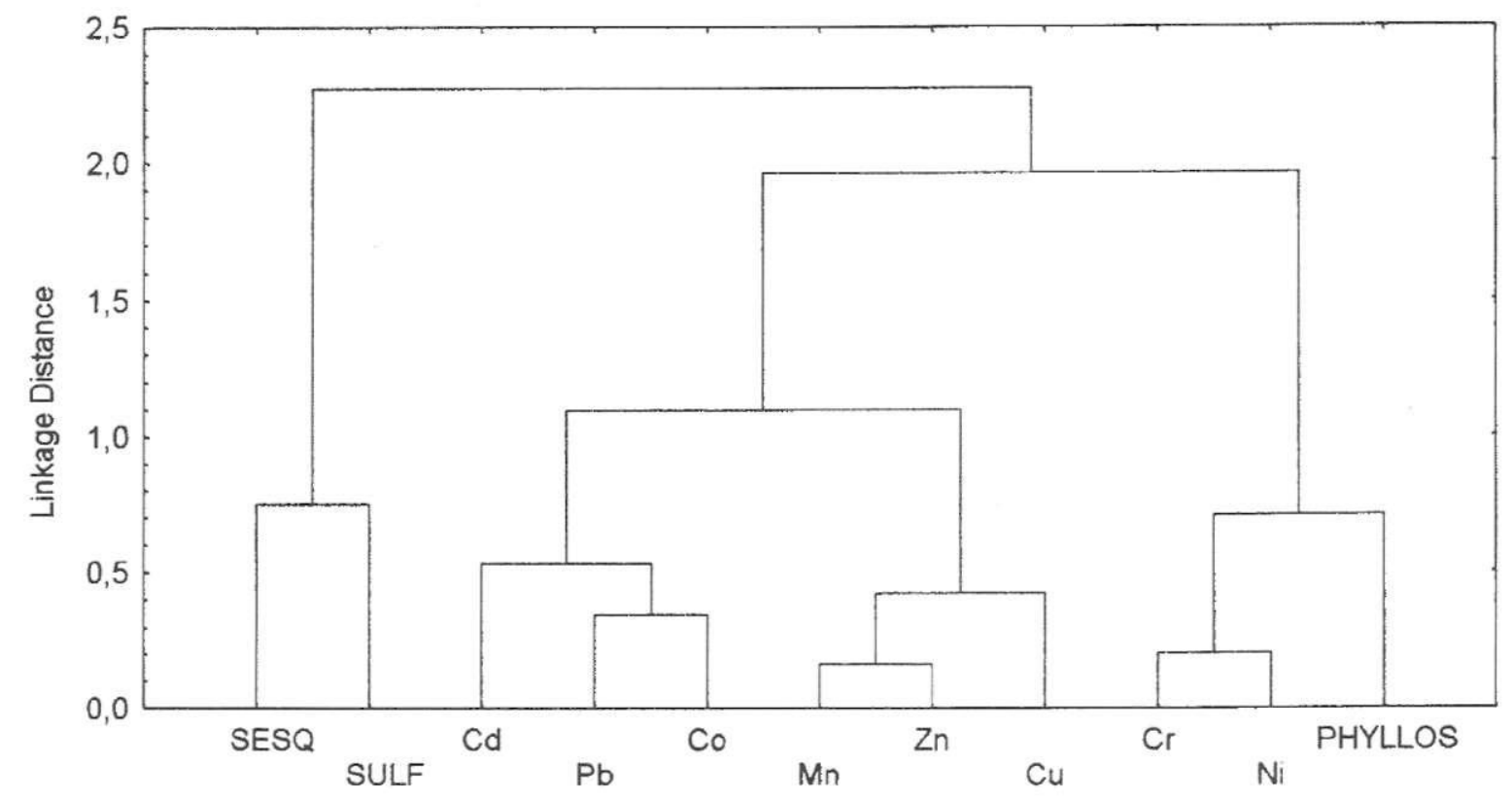

Figure 7-Cluster analysis of mineralogical and chemical variables.

Figura 7-Análise grupal das variáveis mineralógicas e químicas.

Mn concentration in sediments which occur at the top of the third sequence, that is on top of the dunar sediments, indicated the prevalence of more oxidising processes.

\section{REFERENCES}

BUTCHER, S.; CHARLSON, R.; ORIANS, G. \& WOLFE, G. (1994) Global biogeochemical cycles, Academic Press, London, $380 \mathrm{p}$.

DAVIS, J. C. (1986) - Statistics and Data Analysis in Geology. Wiley and Sons, New York, $646 \mathrm{p}$.

GRANJA, H. \& CARVALHO, G. (1991) - Processos geológicos durante o Plistocénico e o Holocénico na zona costeira do noroeste de Portugal. Memorias e Notícias, Univ. Coimbra, 112, p. 57-66.

GRANJA, H. \& CARVALHO, G. (1994) - How can the Holocene help to understand coastal zone evolution? Proceedings of the Second International Symposium EUROCOAST - LITTO$R A L^{\prime} 94,1$, p. 149-167.

IMBRIE, J. \& VAN ANDEL, T. H. (1964) - Vector analysis of heavymineral data. Bulletin of the Geological Society of America, 75, p. 1131-1156.

JORESKOB, K. G; KLOVAN, J.E. AND REYMENT, R. A. (1976) Geological Factor Analysis. Elsevier, Amsterdam, 178 p.

LÓPEZ-AGUAYO, F. \& GONZALEZ LOPEZ, M. (1995) - Fibrous clays in the Almazan basin (Iberian range, Spain): Genetic pattern in a calcareous lacustrine environment, Clay Minerals, 30, p. 395-406.

MACHADO, A.; SILVA, A.P.; ROCHA, F. \& GOMES, C. (1995) Contribuição da mineralogia das argilas para o estudo paleogeográfico das formações areno-pelíticas da Praia de Cortegaça (Ovar). Memórias, Mus. Lab. Miner. Geol. Porto, 4, p. 647-652.

MEZZADRI, G. \& SACCANI, E. (1989) - Heavy mineral distribution in Late Quaternary sediments of the southern Aegean sea: implications for provenance and sediment dispersal in sedimentary basins at active margins. Journal of Sedimentary Petrology, 59, p. 412-422.

MOSSER, C. (1980) - Etude géochimique de quelques elements traces dans les argiles des alterations et des sediments, Sc. Géol., Mémoire Univ. Louis Pasteur Strasbourg, 63, 230p.

REYMENT, R. \& JÕRESKOB, K.G. (1993) - Applied Factor Analysis in the Natural Sciences. Cambridge Univ. Press, Cambridge: $369 \mathrm{p}$ !

ROCHA, F. J. F. T. (1993) —Argilas aplicadas a estudos litoestratigráficos e paleoambientais na Bacia Sedimentar de Aveiro. $\mathrm{PhD}$ thesis, Universidade de Aveiro, $399 \mathrm{p}$.

SCHULTZ, L: G. (1964) - Quantitative interpretation of mineraiogical composition from X-ray and chemical data for the Pierre Shale. United States Geological Survey Professional Paper 391-C, p. 1-31.

SILVA, A. P.; MACHADO, A.; ROCHA, F. \& GOMES, C. (1997) Depósitos quaternários da Praia de Cortegaça (Ovar): caracterização mineralógica, evolução paleoambiental e oscilações climáticas. Estudos do Quaternário, A.P.E.Q., 1, p. 73-82.

THOREZ, J. (1976) - Praticai identification of clay minerals.

- Editions G. Lelotte, Belgique, 99 p. 